\title{
FTA Law in WTO Dispute Settlement: Peru-Additional Duty and the Fragmentation of Trade Law
}

\author{
GREGORY SHAFFER * \\ University of California, Irvine School of Law \\ L. ALAN WINTERS* * \\ University of Sussex
}

\begin{abstract}
There is a serious imbalance between the sclerosis of the political system of the World Trade Organization (WTO) and the automatic adoption of WTO Appellate Body judicial reports. The question is whether the WTO Appellate Body will recognize bilateral political agreements (such as under Free Trade Agreements, FTAs) that modify WTO obligations between two parties. In addressing this question, the Appellate Body decision in Peru-Additional Duty on Imports of Certain Agricultural Products is important. The decision addressed the availability of defenses under FTAs in WTO disputes, as well as under public international law generally. After critically assessing the decision, we set forth a series of judicial and political choices for addressing the interaction of WTO and FTA rules going forward. In particular, we contend that clear modifications of WTO commitments under an FTA should be recognized by WTO panels as a defense, but subject to the FTA itself complying with WTO requirements under GATT Article XXIV. The case is important not only for trade specialists, but generally for policymakers and scholars of global governance in a world of fragmented international treaties.
\end{abstract}

The case Peru-Additional Duty on Imports of Certain Agricultural Products, ${ }^{1}$ brought by Guatemala, is among the most important cases before the World Trade Organization (WTO) in recent years. Mundanely, the case addressed the consistency with WTO rules of Peru's Price Range System (PRS) (Sistema de

\footnotetext{
*Email: gshaffer@law.uci.edu

**Email: L.A.Winters@sussex.ac.uk

We thank Kym Anderson, Lorand Bartels, Tomer Broude, Carl Hamilton, Stefano Inama, Alejandro Jara, Tim Josling, Petros Mavroidis, Joost Pauwelyn, Joel Trachtman, and participants at a workshop at the European University Institute and at the University of Sussex WTO Study Group for comments. We also thank Manuel Tong Koecklin and Boanerges Rodriguez Orellana for research assistance. All errors remain our own. A fuller analysis is available in our working paper Shaffer and Winters (2016).

1 Peru - Additional Duty on Imports of Certain Agricultural Products (Peru-Agricultural Products), WT/DS457/R (27 November, 2014), WT/DS457/R/Add.1 (27 November, 2014), WT/DS457/AB/R (20 July, 2015) and WT/DS457/AB/R.Add.1 (20 July, 2015).
} 
Franja de Precios) for four categories of agricultural products (milk, maize, rice, and sugar), pursuant to which Peru's tariffs could vary fortnightly as a function of historical world prices. More systemically, since Peru and Guatemala agreed in a bilateral Free Trade Agreement (FTA) that 'Peru may maintain its Price Range System', the Appellate Body decision addressed the interaction of WTO law with FTA rules, as well as public international law generally. The FTA provided, 'in the event of any inconsistency' between WTO rules and FTA rules, the FTA rules 'shall prevail', but that is not how the case turned out. The case is important for trade policymakers and scholars addressing a world of fragmented international treaties and institutions.

The dispute involved two central issues. The first was whether Peru's PRS violated Article 4.2 of the WTO's Agreement on Agriculture because it constituted a 'variable import levy' and thus was an 'other duty or charge' in violation of Article II:1(b) of the General Agreement on Tariffs and Trade (GATT) 1994. At first glance, this was easy. The panel and Appellate Body simply applied the Appellate Body's earlier jurisprudence in Chile-Price Band System ${ }^{2}$ to a related set of facts. In doing so, it clarified how to approach and analyze price range systems under WTO rules.

The second issue concerned the relation of these WTO rules to the 2011 FTA between Peru and Guatemala that arguably permitted Peru's price range system. ${ }^{3}$ It poses the question of which rules apply in a defense before the Appellate Body: the Appellate Body's interpretation of WTO rules in clinical isolation of the FTA, or WTO rules in light of the parties' agreement in the FTA? The answer to that question implicates the following fundamental institutional question: Who decides, a bilateral political process or a multilateral judicial one (Shaffer and Trachtman, 2011)? The panel avoided this issue because the FTA in question had not been ratified, but the Appellate Body tackled it head on, assessing the applicability of the FTA's rules regardless of its status, raising systemic questions of trade governance. After critically assessing the Appellate Body decision, Part II sets forth a series of judicial and political choices for addressing the interaction of WTO and FTA rules going forward. In particular, it contends that clear modifications of WTO commitments under an FTA should be recognized by WTO panels, but subject to the FTA itself complying with GATT requirements for FTAs under GATT Article XXIV.

The relationship between multilateral and bilateral trade rules is becoming ever more important. The WTO has become largely dysfunctional as a multilateral negotiating forum, but trade negotiations and agreements proliferate in other

2 Appellate Body Report, Chile-Price Band System and Safeguard Measures Relating to Certain Agricultural Products, WT/DS207/AB/R (adopted 23 September, 2002) (Chile-Price Band System).

3 See Organization of American States, 'Foreign Trade Information System, Information on Peru, Trade Agreements', http://www.sice.oas.org/ctyindex/PER/PERagreements_e.asp (last visited 28 December 2016). 
bilateral and plurilateral venues. There is a serious imbalance between the sclerosis of the WTO's political process and the automatic adoption of WTO Appellate Body reports, This imbalance is brought to light where the Appellate Body interprets the meaning of ambiguous provisions, and the losing party then challenges its authority by accusing it of illegitimate judicial activism and 'gap filling', especially when the losing party is a powerful country such as the United States. Such a situation could undermine confidence in the WTO, including its so-called 'crown jewel', the WTO dispute settlement system, which has been uniquely authoritative as an international tribunal at the multilateral level, but whose authority appears to be at risk (Shaffer et al., 2016).

\section{The WTO legality of Peru's agricultural price range system}

There are policy trade-offs with agricultural tariff schemes aimed at stabilizing prices. On the one hand, as Saggi and Wu (2016) show, under a simple neoclassical economic model, stabilizing duty-inclusive import prices is harmful in small open economies in economic welfare terms. On the other hand, they note that in models that are more complex, with frictions in factor markets, a lack of insurance markets, and risk aversion, there may be overall welfare benefits, and there will certainly be distributional effects that are socially or politically attractive in the medium term. The latter apply particularly to agriculture in poorer countries, in which the returns to land are important, production decisions have to be taken well in advance of sale, many producers are poor, and food absorbs a high share of poor people's expenditure. The long-run attractions of attempting to stabilize prices nonetheless are less clear because, as the world changes, fixed prices get further out of line and eventually impose severe economic distortions on an economy.

While price range systems and variable levies may have domestic attractions, they shift the burden of volatility onto other countries and undermine the predictability of the import taxes faced by foreign traders. Thus, they impose costs abroad, and countries have adopted international rules to address them.

\subsection{A brief history of variable levies}

Sampson and Snape (1980) trace variable levies (VLs) back to the early nineteenth century in the British Corn Laws and the French echelle mobile of 1819. They slipped into modern policy in the guise of minimum import prices in 1935 in a convention between Belgium and Luxembourg over Benelux's trade policy (Tracy, 1989: 244) and into the Common Agriculture Policy (CAP) of the European Union (EU) in the Stresa conference of 1958 (Tracy, 1994). ${ }^{4}$ After the latter, VLs

4 The European Union is the current name of what once was known as the European Economic Community or the European Communities, albeit following an expansion in the membership. We use the modern name throughout. 
became an iconic part of the CAP, which was often viewed as a major achievement for economic integration and a central support for the maintenance of peace in Europe. The EU consequentially viewed the CAP as fundamentally non-negotiable.

The EU's VLs were designed to achieve a fixed internal price (the so-called threshold price), which was fixed annually by policy quite independently of market forces. The levy was calculated every day to absorb the difference between the cif (cost, insurance, and freight) import price measured at Rotterdam, and the threshold price (adjusted for trading costs); it could be negative if import prices were high. The threshold prices were set at high levels; this generated surpluses in the EU, which were then exported with the help of subsidies. Together these policies fixed the internal price of the affected agricultural products almost precisely at the threshold level and thus insulated European producers and consumers from any need to adjust to market shocks at all. This, in turn, shifted the whole burden of adjustment onto other countries. Agricultural producers in the rest of the world thus saw their agricultural markets eroded and their prices become more volatile. Led by the US they targeted EU policy, including the VLs, very strongly in disputes and the trade negotiations undertaken under the auspices of the GATT. ${ }^{5}$

In the Uruguay Round, the US aimed to eliminate agricultural protection, and from an early date pressed the case for 'tariffying' all trade barriers other than ordinary customs duties - i.e. converting them into tariffs of the same protective effect - and then gradually reducing those tariffs to zero. The Round nearly came to grief several times over agriculture, but at the last moment agreement was reached, including to 'tariffy' non-tariff barriers and then reduce (but not eliminate) the tariff rates. ${ }^{6}$

This agreement was incorporated into the Agreement on Agriculture, Article 4.2 which prohibited 'measures of the kind which have been required to be converted into ordinary customs duties' with its ostensibly clarificatory footnote that these 'include ... variable import levies, minimum import prices ... and similar border measures' (emphasis added). For our purposes, two aspects of the agreement are of note. First, the degree of tariff liberalization achieved was actually rather small and, as early as 1995, commentators were claiming that the Round's main achievement in agriculture was not that it had reduced trade barriers but that the system had been rationalized and that through tariffication the means to future liberalization had been secured (Hathaway and Ingco 1995: 58). If this was all that seven years' hard politicking had produced, it is easy to see why trade officials from the WTO and the agricultural exporting nations became so wedded to the principle of tariffication and the elimination of variable levy and minimum import price schemes.

5 In Shaffer and Winters (2016), we present a simple model of the way in which VLs transmit volatility to the rest of the world.

6 Ibid. summarizes the relevant negotiations over agriculture. 
The second aspect of note is that, as we discuss below, Article 4.2 is ambiguous because 'of the kind' is not precise and the footnote is only illustrative (it says 'include'). However, one can arguably see the intent of the negotiations because the staff document issued immediately after the Agreement was signed to guide its implementation - the so-called 'Modalities' (GATT, 1993)-states in Annex III, Section A, paragraph 1:

The policy coverage of tariffication shall include all border measures other than ordinary customs duties such as: quantitative import restrictions, variable import levies, minimum import prices ... and any other schemes similar to those listed above. (emphasis added)

Although the Modalities state that they 'shall not be used as a basis for dispute settlement proceedings' (p. 1), the text makes clear the expectation that everything other than 'ordinary customs duties' was liable to tariffication.

These elements of the Agreement on Agriculture were clearly aimed at the EU, which is large enough to impose material costs on its trading partners via both the terms-of-trade effects of protection and the transmission of instability. In contrast, if a small country such as Peru were guilty of such behaviour, its effect on the rest of the world would be correspondingly small and therefore may not be worth contesting. However, first, even a small economy may be large to one of its neighbours if the latter depends heavily on it for trade. Second, if every small country behaved in this way, the effects would add up to something significant. Third, even violations by insignificant players can undermine the credibility of the system and thus increase the chances that larger players will transgress. Peru fits this situation - it is not large enough to impose serious costs on the vast majority of trading nations - but given the almost iconic status of VLs in the struggle to create the WTO, it might be felt that to allow one to pass unchallenged was a step too far.

\subsection{Peru's price range system}

Peru's PRS covers 45 agricultural products, separated into four general categories: milk, yellow maize, rice, and sugar. ${ }^{7}$ Within each category, one tariff line is designated a 'marker' product and all others as 'associated' products. Floor and ceiling prices are determined for each marker product on the basis of the monthly average f.o.b. (freight on board) prices for the past 60 months on the international reference market for that marker product corrected for US inflation. These prices are updated semi-annually and converted into c.i.f. floor and ceiling prices. ${ }^{8}$ In addition, a

7 For a complete list at the HS-10 level, see Panel Report, Peru-Agricultural Products, para. 7.121. This analysis concerns only the 'marker' products, but Shaffer and Winters (2016) consider the other products briefly.

8 See Panel Report, Peru-Agricultural Products, paras. 7.127-7.135. In addition, for sugar the prices are increased by $44.1 \%$ of the floor price between September 2002 and January 2006 and by $10.7 \%$ of the floor price thereafter - ibid. para 7.131. 
reference price for the marker product is calculated every two weeks as the average international market price for the product over the preceding two weeks, also converted to c.i.f terms. ${ }^{9}$

Whenever the international reference price, $p^{R}$, falls below the floor price, $p^{F}$, a variable additional duty is levied on the imported good to bring its price up to the floor level. Letting $b$ denote an allowance for the import costs associated with marker products, the additional variable duty $A D$ is given by

$$
A D=(1+b)\left(p^{F}-p^{R}\right)
$$

This prevents low import prices from being passed onto Peruvian farmers and consumers. When, on the other hand, the reference price is above the ceiling price, $p^{C}, a$ tariff rebate is issued to the importer to bring the net price down to the ceiling level. It equals

$$
T R=(1+b)\left(p^{R}-p^{C}\right)
$$

This serves to protect Peruvian consumers from undesired price increases on the global market.

The declared objectives of Peru's PRS are to foster price stability by 'neutraliz [ing] the fluctuations of international prices', and to counter the adverse effects of price distortions in international markets and improve domestic competitiveness, which amount to providing an element of protection to farmers. ${ }^{10}$ Our first question, therefore, is: Did the actual design of Peru's PRS achieve its stated objectives?

Even for the marker products, the PRS's stabilization is incomplete and its protection somewhat covert and arbitrary. The system is anchored to the long-run mean world price of the marker products from which we infer that the long-run price is in some sense an objective and hence an appropriate benchmark against which to measure the PRS's performance. A price-band scheme aimed purely at stabilization would allow prices to vary within a band around the mean price $(\mu)$, with more extreme fluctuations in either direction curtailed according to equations (1) and (2) above. The band in the PRS is set equal to the standard deviation of world prices measured over the five year anchor period $(s)$, but instead of spanning the mean price such that the range is $(\mu-s / 2)$ to $(\mu+s / 2)$, it rests on the mean price, giving a range of $\mu$ to $(\mu+s)$. This design feature prevents local prices from falling below the long-run world mean and results in the mean duty-inclusive import price being approximately $s / 2$ above the mean long-run world price $\mu .^{11}$ The value of $s$ clearly depends on the variability of the reference prices over the preceding five

9 Ibid., paras. 7.136-7.139.

10 See Panel Report, Peru-Agricultural Products, para. 7.118. There is also a brief genuflection towards consumers - ibid. para. 7.119 - but it is clearly secondary to the producer interest.

11 The precise amount of the uplift depends on the distribution of the reference prices over the range $\mu$ to $(\mu+\mathrm{s})$. 
years; over our sample of data - see Shaffer and Winters (2016) - $s / 2$ ranges from $3.7 \%$ of the long-run world mean price (for dairy products over early 2002) to $23.6 \%$ (for rice in 2010).

The Peruvian PRS has two other modifications relative to a simple price band. First, as noted above, the additional duty under the PRS was capped so that the sum of the additional duty, the ad valorem tariff (of $0 \%$ after 2010), and (while it lasted) an import surcharge did not exceed the ad valorem rates bound under the Uruguay Round. Peru's bound rates for the four marker products were high $-68 \%$ for all four categories from 2004 onwards - so that this constraint virtually never bound. The second modification is that when prices exceed the ceiling price, Peru caps the rebate it provides importers to the total level of duties (ad valorem and surcharge) they paid. Because Peru's applied rates were low (eventually zero), this restriction constrains the PRS's ability to mitigate the transmission of high world prices, and thus imparts a significant upward bias to the average dutyinclusive import price; that is, the PRS serves to increase Peru's average dutyinclusive prices.

In Shaffer and Winters (2016), we calculate the effects of the PRS on the average level of protection and duty-inclusive price stability for each of the marker products. If the Peruvian authorities were truly aiming to replicate the (long-run) world average prices and to reduce variability about them, a centered PRS would do this quite effectively. However, by grossing up the sugar price, rebasing the PRS to rest on the mean and by limiting rebates to the duties paid, the PRS created a substantial positive bias to mean prices. In three out of the four products, the mean price induced by the actual PRS exceeds that of the reference price and for none of them was variability reduced by more than a quarter. Thus, as it turned out, the PRS functioned generally to protect farmers from low world prices while allowing them to benefit from high world prices. Figure 1 plots the reference and the PRS-adjusted prices for the four products.

The objective of protecting farmers' incomes is particularly salient for sugar, which is the only PRS commodity for which, according to Saggi and Wu (2016), Guatemala exported significant amounts to Peru. When the FTA negotiations between Guatemala and Peru were initiated in October 2010 and signed in December 2011, Peru was levying no additional duty. But by April 2013, when Guatemala sought WTO consultations about the PRS, prices had fallen and the additional duty had risen to about $25 \%$, and it had reached $30 \%$ by September 2013, when the panel was formed. This price change arguably explains why Peru brought the WTO complaint following its signature of the 2011 FTA.

\subsection{The Appellate Body decision on Guatemala's PRS claims}

The first group of WTO legal questions in the case were three-fold: (i) whether Peru's PRS gave rise to variable import levies (or measures similar to them) in violation of Article 4.2 of the Agreement on Agriculture; (ii) whether the PRS involved 
Figure 1. Reference prices and post-PRS prices: four marker products

Dairy

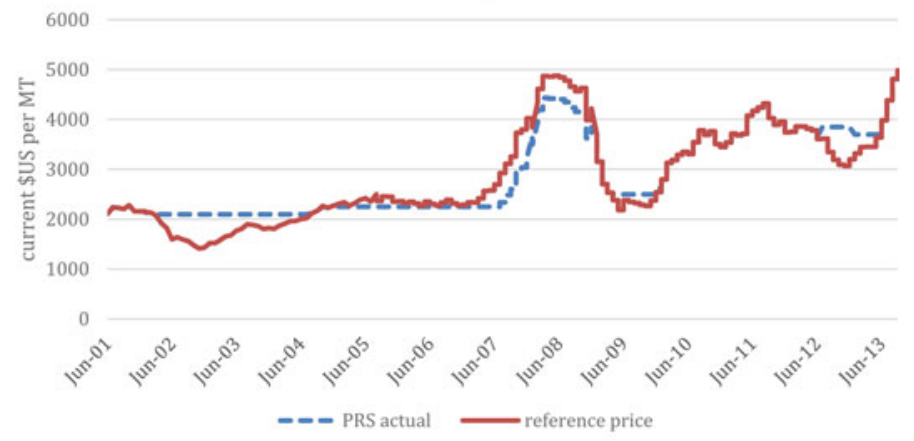

Maize

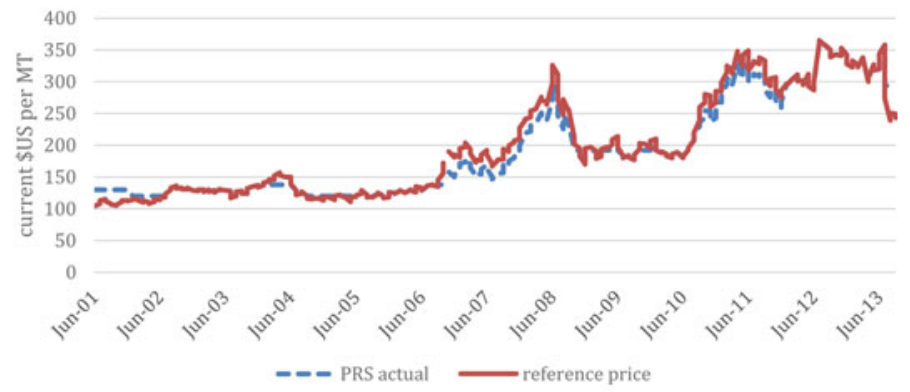

Rice

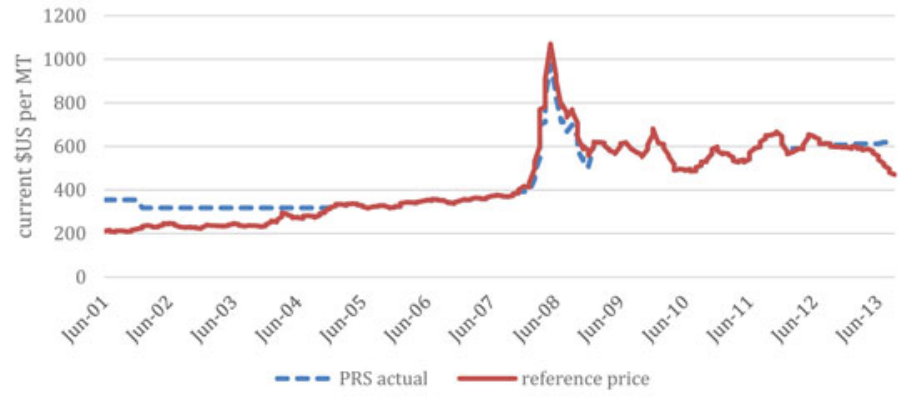

Sugar

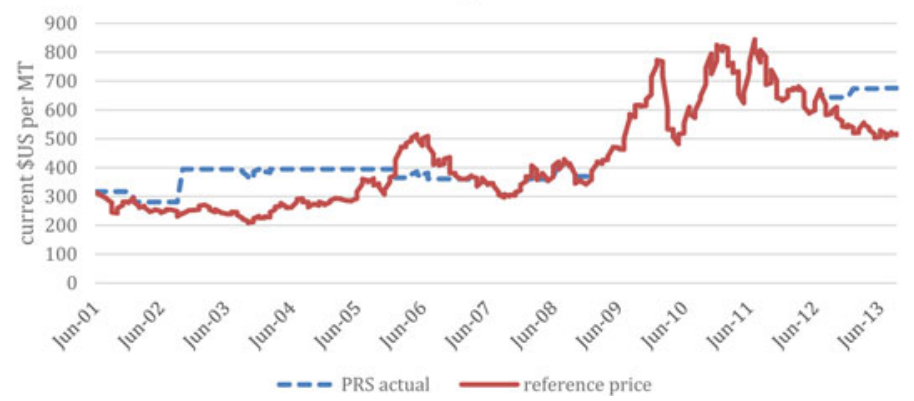


minimum import prices (or measures similar to them) in violation of that same article; and (iii) whether the PRS gave rise to duties that were not 'ordinary customs duties', but rather 'other duties or charges' not listed on Peru's tariff schedule, in violation of Article II:1(b) of GATT 1994.

The panel and the Appellate Body first analyzed the claims under Article 4.2 of the Agreement on Agriculture because these provisions were more specific (and thus lex specialis) in governing the agricultural tariff scheme. From the text of Article 4.2 - given above - the key question was whether Peru's measures were 'of the kind which have been required to be converted into ordinary customs duties'. Since the term 'ordinary customs duties' is not defined, and since the agreement does not specify what 'kind' of measures were required to be converted other than the non-exclusive list contained in the footnote, the text is not without ambiguity. ${ }^{12}$ The panel and Appellate Body thus focused on whether Peru's scheme was a 'variable import levy' or a 'minimum import price', or a measure 'similar' to one, which terms are not defined.

This legal issue was straightforward in light of the Appellate Body's analysis in its 2003 decision in Chile-Price Band System regarding the meaning of these terms. In that case, the Appellate Body found that Chile's price band was sufficiently similar to a variable import levy and a minimum import price so as to contravene Article 4.2 of the Agreement on Agriculture. The panel and Appellate Body both repeatedly cited the Chile-Price Band System precedent to find that the duties were 'variable'. This finding raises the question posed by Saggi and Wu (2016) in their analysis of the panel decision in Peru-Additional Duty as to whether a PRS can be designed to vary less frequently (say once a month, or once every six months) so that it could pass muster under the Appellate Body's analysis. ${ }^{13}$

Once the panel and Appellate Body found that the PRS gave rise to a variable import levy, they easily concluded that the PRS was not an 'ordinary customs duty' within the meaning of GATT Article II.1(b). The determination of the Article 4.2 claim under the Agreement on Agriculture, in other words, effectively determined the GATT Article II(1)(b) claim because the footnote to Article 4.2 of the Agreement on Agriculture notes 'variable import levies' and 'minimum

12 In fact, many Latin American officials were of the view that price range systems were legal so long as the applied tariff did not exceed the tariff binding in its schedule. The Economic System of Latin America (SELA) apparently sought and received assurance from GATT officials that as long as PRS-like policies resulted in a tariff below the bound level, there was no problem, although we have seen no supporting documentation - private communication from Alejandro Jara, former Ambassador of Chile to the WTO, and Deputy Director General of the WTO.

13 Having determined that the PRS gave rise to a variable levy, the Appellate Body did not complete the analysis of whether it also constituted a minimum import price. However, the Appellate Body overruled the Panel on this question and suggested that the PRS may constitute one-see discussion in Shaffer and Winters (2016). 
import prices' as examples of measures that are not 'ordinary customs duties' ${ }^{14}$ As a result, both the panel and the Appellate Body found that the tariff measures were 'other duties and charges' that Peru had not listed in its schedule, so that Peru also violated GATT Article II.1(b).

There may be good legal grounds to maintain that the design, structure, and operation of Peru's measures are similar to a variable import levy and (possibly) a minimum import price. Yet, given that there is some ambiguity regarding the definition of a variable import levy, given that Peru's applied tariffs were set at zero so long as the reference price fell above the floor price, given that Peru was authorized to raise its tariffs to $68 \%$ (WTO tariff binding), and given that Peruvian policy makers see a rationale for a PRS to provide some stability to agricultural markets for farmers, especially poorer ones who otherwise may be unable to tap into insurance markets, it seems worth seeking a solution. The current situation places strains on the system, which, if not resolved through an acceptable dispute outcome or through a mutually agreed settlement, could lead to a Member either raising its applied tariff in a blunt way to block imports (possibly up to its tariff binding), or defying the Appellate Body. The third alternative, which is an interpretation of what happened here, is that the Member may negotiate a political agreement, such as through a series of FTAs, and ask the Appellate Body to recognize those agreements.

The WTO legal dispute in Chile-Price Band System on this issue lasted seven years, from 5 October 2000, when Argentina first filed its complaint, until 7 May 2007, when the Appellate Body issued its Article 21.5 ruling that Chile had still not complied with the Appellate Body ruling of 23 September 2002. ${ }^{15}$ Chile continues to use a price band subject to its WTO tariff binding, a binding that it renegotiated to increase to $98 \%$ for sugar after the WTO ruling. There was, in other words, lots of law, but little action. In the end, the panel and Appellate Body reports had little legal effect, and the two sides moved on.

A similar pattern appears to be developing in response to the Appellate Body decision in Peru-Additional Duty. Following the decision, an arbitrator, Ricardo Ramirez, decided that Peru should comply with the decision by 29 March 2016. Peru maintained its PRS, but with reference prices that will now be published monthly. ${ }^{16}$ In this way, Peru aims to advance an argument that the PRS is no longer a 'variable import levy' (since it only changes monthly), and thus an

14 If the Appellate Body considered the negotiators' intentions as indicated by the Modalities, the determination under Article 4.2 also comes back to the 'ordinary customs duty' question. The modalities make clear that anything that is not an 'ordinary customs duty' was expected to be tariffied regardless of whether it resembled the illustrative policies provided in the footnote.

15 Article 21.5 Appellate Body Report, Chile - Price Band System and Safeguard Measures Relating to Certain Agricultural Products (Recourse to Article 21.5), WT/DS207/AB/RW (adopted 7 May 2007) (Chile-Price Band System).

16 The decree can be found here: http://www.elperuano.com.pe/NormasElperuano/2016/03/28/ 1360415-1.html. 
ordinary customs duty with an applied rate that is less than Peru's tariff binding. Guatemala may commence an Article 21.5 compliance proceeding that will drag the case through more legal hoops.

The question posed before the Article 21.5 compliance panel will be where to draw the line between an 'ordinary customs duty', which countries can periodically change provided the duty remains beneath the tariff binding, and an 'other duty or charge' in the form of a variable import levy which is prohibited. The answer is not obvious, especially if the stated goal of the Agreement on Agriculture is to provide greater predictability for traders. If Peru replaces its PRS with a system of periodically changing its ordinary customs duty through an administrative decision, the changes would be less predictable for traders. At the end of the day, the Appellate Body's legal ruling, as that in Chile-Price Band System, may be largely ignored or its effect undercut through other means, such as through a general safeguard measure, or by periodically raising the applied tariff rate. The political salience for Peru appears simply too great, as reflected in Peru's efforts to sign FTAs with its major trading partners regarding the PRS.

\section{Peru's defense: relation of the FTA to WTO rules in a WTO dispute}

The ability to use a PRS for this set of products (milk, maize, rice, and sugar) is politically salient for Peru. Between 2005 and 2015, Peru signed at least 15 FTAs covering at least 50 WTO members: Australia, Brunei, Canada, Chile, China, Colombia, Costa Rica, the EFTA states, the European Union (and its member states), Guatemala, Honduras, Japan, Malaysia, New Zealand, South Korea, Mexico, Panama, Singapore, Vietnam, and the United States, in which these WTO members accepted Peru's PRS. Peru negotiated such acceptance under the Trans-Pacific Partnership (TPP) mega-regional, and thus including the US in the event the US ratifies the TPP (for FTA texts, see Annex 1, Saggi and Wu, 2016). ${ }^{17}$ The WTO Appellate Body may have found that Peru's PRS was unacceptable under WTO rules; but Peru negotiated specific rules accepting the PRS with its most important trading partners.

In the case of the Peru-Guatemala FTA, Guatemala agreed that 'Peru may maintain its Price Range System established in Decree no. 1152001EF'. Although, in the first paragraph of FTA Article 1.3, the parties 'confirm their existing mutual rights and obligations under the WTO Agreement and other agreements to which they may be parties', the second paragraph clarifies that, '[i]n the event of any

17 The TPP is not as clear as the Guatemala-Peru FTA and the other FTA texts, but nonetheless accepts Peru's PRS. It provides: '(i) the ad valorem duty shall be eliminated entirely on the date of entry into force of this Agreement for Peru; and (ii) the specific duty derived from the application of the Peruvian Price Range System established in the D.S. $\mathrm{N}^{\circ} 115-2001-\mathrm{EF}$ and its amendments, any future modification or any succeeding system shall be excluded from any tariff elimination'. TPP, Annex 2-D, Tariff Schedule of Peru, General Notes, paras. 4(f) and (g). 
inconsistency between this Treaty and the agreements referred to in paragraph 1 [such as the WTO Agreement], this Treaty shall prevail to the extent of the inconsistency, unless otherwise provided in this Treaty'.

The critical question is: What is the relation of FTA provisions as a defense to WTO rules? In public international law, in the event of a conflict between provisions in two agreements, two canons of interpretation help resolve it. One is the rule of lex posterior, codified in Article 30(3) and (4) of the Vienna Convention of the Law of Treaties (Vienna Convention), which provides that a later-in-time rule prevails over the earlier one. The other is the principle of lex specialis, cited in WTO jurisprudence, which provides that where two sets of laws govern the same factual situation, the more specific law overrides the more general one. Where one rule is a multilateral rule and the other a bilateral rule, Article 41 of the Vienna Convention further provides that two parties may modify a multilateral treaty between themselves, under certain conditions, reflecting the lex posterior rule. These rules are grounded in the principle of the contractual freedom of states to specify and modify the rights and obligations existing between them.

The FTA provision permitting Peru's PRS, however, was clearly inconsistent with the Appellate Body's former interpretation of applicable WTO rules. The existence of such inconsistency raises a series of questions that the Appellate Body could address more clearly. First, what is the applicable law before the WTO once a WTO tribunal is seized with a WTO complaint: only the WTO 'covered agreements' or the WTO agreements in light of other international law? Second, if a WTO tribunal may refer to other international law (such as another international treaty) as a defense (whether as a waiver of the right to bring a WTO claim or as a modification of the rules applicable between the parties), was there a conflict between the FTA rules and WTO rules, such that conflict-of-laws rules apply? Third, if conflict-of-laws rules apply, what was the parties' intent under the FTA in the event of an inconsistency or conflict with WTO rules? Fourth, if a WTO dispute settlement panel is to recognize a defense under an FTA, must the FTA itself comply with WTO requirements?

\subsection{Peru's possible defenses}

We commence this section with a brief overview of four primary ways Peru could raise a defense to Guatemala's WTO complaint in relation to the FTA, had the FTA been in effect, because the Appellate Body interpreted the relation of WTO rules regardless of the FTA's legal status. ${ }^{18}$ First, Peru could maintain that Guatemala had expressly waived its rights under the FTA to bring a WTO complaint

18 The Appellate Body noted that Peru had yet to ratify the FTA, and thus it is not clear that Peru is a 'party' to the FTA. Yet, the Appellate Body stressed that its findings were 'irrespective of the status of the FTA as not being ratified by both parties'. AB Report, Peru-Agricultural Products, para. 5.106, and para. 5.28 . 
against the PRS. Second, as a variant of the waiver defense, Peru could argue that Guatemala had expressly consented to the PRS, precluding a finding of wrongfulness under customary international law. Third, Peru could contend that, under customary rules of interpretation, WTO rules should be interpreted between FTA parties in light of the FTA. Fourth, Peru could maintain that the FTA modified WTO rules as between the FTA parties, and such modification should be recognized as a defense to the WTO complaint. Note that all these defenses serve to prevent or otherwise defend only against Guatemala bringing a WTO claim, not to justify the PRS so far as it applied to any other WTO Members.

On the first defense, the WTO Agreement has a provision on waivers (Article X), but this provision governs waivers granted by all WTO Members, not the waiver by one Member in an inter se agreement with another Member. The Appellate Body has recognized the ability of a Member to waive a claim in relation to a mutually agreed solution to a WTO complaint in the EC-Bananas 21.5 (US) case $(2008)^{19}$. The question arises whether a WTO Member can also agree to a waiver outside of a mutually agreed solution to a specific WTO complaint. In this respect, Article 45 of the International Law Commission's Articles on Responsibility of States (International Law Commission 2001) provides that 'the responsibility of a State may not be invoked if ... the injured State has validly waived the claim'.

On the second defense, which is a variant of the first, Article 20 of the ILC Articles provides that "valid consent by a State to the commission of a given act by another State precludes the wrongfulness of that act in relation to the former State'. Consent is 'a basic international law principle' that can be raised as a defense. ${ }^{20}$ It does not involve a change in substantive obligations (such as the modification of rights and obligations), but rather recognition that a state can consent to an action or measure otherwise in contravention of an international legal obligation, and that when it does it cannot then claim responsibility from the other state. Article 20, however, would not apply if the WTO Agreement precludes the giving of bilateral consent to a WTO-inconsistent measure, and rather requires a waiver granted by all WTO Members in compliance with Article X of the WTO Agreement. Alternatively, a WTO panel might not permit such a defense if the FTA containing the consent itself is in violation of GATT Article XXIV requirements.

On the third defense, Article 3.2 of the WTO Dispute Settlement Understanding (DSU) provides that the WTO agreements are to be interpreted 'in accordance with customary rules of interpretation of international law'. Such customary rules provide means for interpreting WTO provisions, including in light of other international law. However, such other international law should be relevant to the

19 Appellate Body Report (United States), European Communities - Regime for the Importation, Sale and Distribution of Bananas (Second Recourse to 21.5), WT/DS27/AB/RW/USA (adopted 26 November 2008).

20 ILC Articles, Article 20, Commentary, para. 1, p. 72. 
interpretation of the WTO provisions in question, and it cannot modify their terms, but only help clarify their meaning. Moreover, such interpretations will apply to all WTO Members, and not just to the parties to a dispute.

On the fourth defense, Article 41 of the Vienna Convention permits parties to modify a multilateral treaty inter se so long as the following conditions apply:

(i) 'the modification in question is not prohibited by the treaty';

(ii) the modification 'does not affect the enjoyment by the other parties of their rights under the treaty';

(iii) the modification 'does not relate to a provision, derogation from which is incompatible with the object and purpose of the treaty as a whole'.

The question is whether all of these conditions apply. The WTO treaties do not (at least expressly) prohibit inter se modifications. The modification arguably does not affect the de facto enjoyment of other WTO parties of their rights, and neither is it incompatible with the object and purpose of the WTO treaties as a whole. $^{21}$

Many scholars nonetheless argue that WTO panels and the Appellate Body are limited to interpreting the WTO 'covered agreements', which are lex specialis, so that only provisions of the WTO agreements, as interpreted in accordance with customary international law, can be used as a defense to a WTO complaint (Trachtman, 1999, 2004; Marceau, 2001). These scholars cite various provisions of the DSU for support, such as DSU Article 3.2, which provides that the DSU 'serves to preserve the rights and obligations of Members under the covered agreements', and DSU Article 19.2, which provides that panel and Appellate Body rulings 'cannot add to or diminish the rights and obligations provided in the covered agreements' (emphasis added). Bartels (2001) maintains that these provisions constitute an implicit conflicts rule, and provide that WTO texts prevail in the event of a conflict.

Alternatively, however, these provisions can be viewed as statements against judicial activism in the interpretation of WTO legal texts, while saying nothing about contracting out of conventional public international law conflicts rules, especially since they contain no conflicts language within them. None of these WTO provisions, for example, is like Article 103 of the UN Charter that provides, in the event of a conflict with any other international agreement, the 'obligations under the present Charter shall prevail'. Thus, other scholars stress that the WTO is an international treaty and, as such, is part of public international law (Pauwelyn, 2003a, 2003b). They contend that, although WTO panels only have jurisdiction to hear complaints under WTO law, the WTO agreements do not provide that WTO Members have contracted out of defenses that they otherwise

21 The PRS, to the extent that it is applied to all WTO Members, affects other WTO Members rights in principle because it shifts volatility onto them, but taken in isolation Peru is small enough that these effects are probably negligible in practice. 
have under public international law, including under other treaties pursuant to Article 41 of the Vienna Convention and Article 20 of the ILC Articles.

To the extent that one accepts that other international law may apply as a defense, one must then assess whether there is a conflict between the two treaties. Some scholars maintain a narrow definition of a 'conflict', one in which a conflict occurs only if it is impossible to comply with both treaties simultaneously. Under such view of a 'conflict', obligations always prevail over permissions. Since the FTA provision is permissive and not obligatory, there would thus be no conflict. We find (with Pauwelyn, 2003a) that such a narrow definition of conflict would fail to recognize the intent of the parties, thereby curtailing Members' policy space against their express agreement.

\subsection{FTA defenses raised by Peru: the Panel and Appellate Body Rulings}

Peru's failure to ratify the FTA constrained the defenses it could raise, and so Peru attempted to base its defense largely on WTO texts. Peru argued before the panel that Guatemala had failed to act in 'good faith' in bringing its complaint, which violated Guatemala's obligations under Articles 3.7 and 3.10 of the DSU. ${ }^{22}$ Because the FTA was not in force, Peru cited Article 18 of the Vienna Convention which provides that '[a] State is obliged to refrain from acts which would defeat the object and purpose of a treaty' that it has signed and that is in the process of ratification. As an alternative argument, Peru maintained that the FTA had modified Guatemala's rights under the WTO framework by maintaining that Peru could maintain its PRS, but this was a weak argument because the FTA was not in effect.

In response, the panel grounded its analysis on the fact that the FTA was not in force, and that a 'treaty only begins to produce legal effects and bind the parties from the moment it enters into force'. ${ }^{23}$ Since the treaty was not in effect, it created no legal obligations on Guatemala. On the issue of modification, the panel ruled: '[i]n light of this fact [that the treaty was not ratified], it is not necessary for this Panel to express an opinion on whether the parties may, through the FTA, modify between themselves their rights and obligations under the covered agreements, or whether there is a conflict of rules between the FTA and the covered agreements'.24

In its appeal, Peru expanded its defense to contend that Guatemala had waived its rights to bring a WTO complaint against Peru's PRS after Guatemala accepted

22 DSU Article 3.7, in relevant part, provides 'Before bringing a case, a Member shall exercise its judgement as to whether action under these procedures would be fruitful.' DSU Article 3.10 provides, in relevant part, 'It is understood that requests for conciliation and the use of the dispute settlement procedures should not be intended or considered as contentious acts and that, if a dispute arises, all Members will engage in these procedures in good faith in an effort to resolve the dispute.'

23 Panel Report, Peru-Agricultural Products, para. 7.88 .

24 Ibid., para. 7.528. 
the PRS in the FTA. Peru bolstered this defense by citing Articles 20 and 45 of the ILC's Articles on Responsibility of States. Peru, however, no longer maintained that the FTA had modified its WTO obligations, but rather contended that the WTO provisions should be interpreted in light of the FTA. The Appellate Body, since its creation, has recognized that WTO rules are to be interpreted in light of the customary rules set forth in Articles 31 and 32 of the Vienna Convention. Article 31(3) provides that the interpreter will take into account ' $[a]$ ny subsequent agreement between the parties regarding the interpretation of the treaty or the application of its provisions ... and [a]ny relevant rules of international law applicable in the relations between the parties' (emphasis added). Peru maintained that the FTA was a 'subsequent agreement between the parties' to the dispute, and that ILC Articles 20 and 45 were 'relevant rules of international law' for the interpretation of the covered agreements.

In response to the good faith and waiver defenses, the Appellate Body found that Guatemala had 'not clearly waived its right to recourse' to the DSU. Importantly, the Appellate Body did 'not exclude the possibility of articulating the relinquishing of the right to initiate WTO dispute settlement proceedings in a form other than a waiver embodied in a mutually agreed solution [to a WTO dispute]'. ${ }^{25}$ Nonetheless, it stressed a series of conditions for it to recognize such a waiver. First, 'any such relinquishment must be made clearly' (emphasis added). ${ }^{26}$ Second, such relinquishment 'should be ascertained ... in relation to, or within the context of, the rules and procedures of the DSU'. ${ }^{27}$ Third, the relinquishment may not go 'beyond the settlement of specific disputes'. ${ }^{28}$ Fourth, the Appellate Body warned that 'the DSU emphasizes that "[a] solution mutually acceptable to the parties" must be 'consistent with the covered agreements' (emphasis added). ${ }^{29}$

These conditions will need to be clarified, but appear to go beyond WTO textual requirements. For example, why must a waiver apply to a specific dispute rather than a general obligation, so long as no other WTO party is harmed? ${ }^{30}$ Moreover, the last condition suggests that WTO Members can never waive their rights to bring a WTO complaint regarding a WTO-inconsistent provision. But what else is a waiver except permission for a party to engage in conduct that otherwise would be inconsistent with its obligations? Moreover, the provision it cites, DSU Article 3.7, only provides that a solution 'consistent with the covered agreements is clearly to be preferred', not that it is required. Parties should be able to consent among themselves to measures that the Appellate Body would otherwise

25 AB Report, Peru-Agricultural Products, para. 5.25

26 Ibid., para 5.25 .

27 Ibid.

28 Ibid., fn. 106.

29 Ibid.

30 It is unclear what the Appellate Body means by a specific dispute. It could refer narrowly to a WTO complaint, or it could refer broadly to a general measure that is subsequently litigated under the DSU. 
find violate WTO rules, provided other WTO Members are not adversely affected, as reflected in Article 20 of the ILC Articles. The Appellate Body's dicta is thus problematic to the extent it calls on panels to ignore parties' clearly expressed intent.

To support its conclusion, the Appellate Body found that it was ambiguous in this case whether Guatemala consented to modify WTO rules with Peru, and thus waive its WTO rights, especially since FTA Article 1.3 confirms the FTA parties' WTO rights. ${ }^{31}$ The Appellate Body thus saw 'no reason to address further Peru's arguments that ILC Articles 20 and 45 provide additional support for its [waiver] argument', or Peru's arguments regarding Article 18 of the Vienna Convention. ${ }^{32}$ The Appellate Body's position, however, is counterbalanced by the fact that the FTA expressly provides that 'Peru may maintain its Price Range System established in Decree no. 1152001EF', and that the FTA contains a clear conflicts clause which provides: 'In the event of any inconsistency between this Treaty and the agreements referred to in paragraph 1 [the WTO agreements], this Treaty shall prevail to the extent of the inconsistency, unless otherwise provided in this Treaty' (emphasis added).

On the issue of interpretation, the Appellate Body found that WTO rules could not be interpreted to permit the PRS in light of the FTA because to do so would manifestly contradict the WTO's text, as previously interpreted by the Appellate Body. As the Appellate Body noted, it would have to interpret the terms 'shall not maintain' in Article 4.2 of the Agreement on Agriculture as 'may maintain' in light of the FTA. ${ }^{33}$ The Appellate Body rightly stressed that Article 31(1) of the Vienna Convention provides that the 'treaty shall be interpreted' as a whole, and 'not the treaty as it may apply between some of its parties'. ${ }^{34}$ The Appellate Body correctly found that a WTO provision should not have different meanings for different WTO Members.

Although Peru focused its defense before the Appellate Body on the 'interpretation' of WTO provisions, the Appellate Body rightly noted that Peru implicitly argued that the FTA had 'modified' its obligations toward Guatemala. ${ }^{35}$ In dicta, the Appellate Body then addressed under what conditions it would recognize such modification. It strongly suggested, 'assuming arguendo that the provision of the FTA allowed Peru to maintain a WTO-inconsistent PRS', that Peru could not modify its WTO commitments through the FTA. ${ }^{36}$ The Appellate Body noted that the WTO contains its own provisions for the amendment of WTO rules

31 See AB Report, Peru-Agricultural Products, paras. 5.26-5.28. See also paras. 5.110-5.111.

32 Ibid., para. 5.28 , fn. 109.

33 Ibid., para 5.94

34 Ibid., para. 5.95. The Appellate Body also disagreed with Peru that ILC Articles 20 (regarding valid consent) and 45 (regarding valid waiver) are 'relevant' rules of international law within the meaning of Article 31(3)(c) of the Vienna Convention for purposes of interpreting WTO provisions. Ibid., para. 5.104. 35 Ibid., paras. 5.96-5.97.

36 Ibid., para. 5.111. 
(Article X of the WTO Agreement) and for their interpretation by the membership (Article IX), as well as rules for the creation of an FTA that might be used as a defense to a WTO complaint (Article XXIV of GATT 1994). ${ }^{37}$ The Appellate Body suggested that these provisions exclusively cover the modification of WTO rules, and therefore 'we are not convinced' that Article 41 of the Vienna Convention applies. ${ }^{38}$ It suggested, in other words, that WTO Members had contracted out of Article 41 of the Vienna Convention through the WTO's own rules on amendments and exceptions.

Regarding the application of the GATT Article XXIV exception for FTAs, the Appellate Body noted two conditions for raising a defense under an FTA, citing its earlier decision in Turkey-Textiles ${ }^{39}$ : (i) that the measure at issue is introduced upon formation of the FTA that meets Article XXIV requirements; and (ii) that the FTA would have been prevented were the party not permitted to introduce the measure. ${ }^{40}$ Neither of these two conditions would have been met because Peru's PRS preceded the FTA and arguably was not necessary for the FTA (although Peru certainly suggested that it was important given its refusal to ratify the agreement after Guatemala commenced the WTO dispute). Moreover, the Appellate Body stressed that the GATT's FTA exception is to facilitate trade and closer integration, and not to provide 'a broad defense for measures in FTAs that roll back on Members' rights and obligations under the WTO agreements' ${ }^{41}$

This Appellate Body dicta again problematically refuses to recognize WTO Members' contractual freedom to update and modify the rules that apply between them through FTAs, such as to preserve policy space for the stabilization of agricultural prices. We contend that the WTO Appellate Body was wrong in suggesting that WTO law forecloses the use of all inter se modifications, especially the provisions that the Appellate Body cited - Article X of the WTO Agreement and GATT Article XXIV. First, Article X of the WTO Agreement provides procedures where amendments apply to all WTO Members, but it does not contract out of Article 41 of the Vienna Convention regarding inter se modifications between WTO Members that meet Article 41's conditions. Second, GATT Article XXIV provides an exception to WTO most-favored-nation (MFN) rules where a party forms an FTA or a customs union that meets specified conditions. But it does not contract away parties' contractual freedom to modify WTO provisions inter se so long as the FTA meets those conditions. GATT Article XXIV is about inter se trade liberalization as a condition for a deviation from MFN treatment; it is not about inter se consent to a non-MFN related measure that does not adversely

37 Ibid., para. 5.112 and fn. 300.

38 Ibid., para. 5.111.

39 Appellate Body Report, Turkey - Restrictions on Imports of Textile and Clothing Products, WT/ DS34/AB/R (adopted 22 October 1999).

40 Ibid., para. 5.115.

41 Ibid., para. 5.116. 
affect other WTO Members (i.e. outside the object of the GATT Article XXIV exception clause). Moreover, GATT Article XXIV is an exception to a GATT obligation, and not to the WTO Agreement on Agriculture, which was at the center of the dispute.

It seems wrong to insist that the WTO Members in 1994 foreclosed themselves from ever entering into inter se modifications of WTO rules that could be recognized as a defense to a WTO complaint between themselves for the rest of time, unless the entire WTO membership agrees (in practice by consensus) to amend the WTO agreements.

\subsection{What can be done: three judicial and three political options}

Given changes in global trade and Member preferences since the WTO agreements' conclusion in 1994, and given that the WTO political mechanism is blocked so that rules, interpretations, and understandings are not being updated or clarified through the WTO's political processes, it is important to find appropriate ways for WTO Members to define their trade relations through a political mechanism. This is particularly the case given complaints by some WTO members and commentators that the Appellate Body has engaged in judicial activism and 'gapfilling' in interpreting WTO rules. To the extent that the WTO text itself is ambiguous, as Bagwell and Sykes (2004) wrote regarding the Appellate Body's earlier Chile-Price Band System decision), there is an even more demanding case that the Appellate Body should defer to Members to clarify, through a political mechanism, their understanding of the rules that apply between them. Even if the WTO rules are patently clear, if the WTO political process is blocked, Members should be able to negotiate the rules that apply between them outside of the WTO, as recognized under public international law.

So what can be done? There are a number of options that can be pursued, judicially and politically. Judicially, the Appellate Body can fend off the application of FTA rules or find ways to facilitate greater coherence between WTO and FTA rules. Politically, WTO Members can take different initiatives that vary in their ambition.

\section{Three judicial options}

A first judicial option, reflected in the Appellate Body's ruling, is to prohibit defenses under FTAs other than express waivers of the right to bring a WTO complaint. Under this scenario, WTO rules exist in parallel to FTAs, but FTA rules cannot be invoked before the WTO dispute settlement system as a defense unless there is an express waiver of a WTO right. The Appellate Body left the door ajar for a Member to expressly waive the right to bring a WTO claim through an FTA so long as the waiver is clear. ${ }^{42}$ Peru thus might have prevailed had the 
parties added a sentence such as 'Guatemala consents to the PRS and waives any rights it may have to challenge the PRS under WTO rules.' But this position does not make it easy for negotiators of FTAs since it is impossible to know in advance how a measure such as the PRS will be applied, and the WTO dispute settlement system is more effective than FTA dispute settlement mechanisms. Such a position will constrain the utility of negotiating exceptions under an FTA to enhance policy space, such as Peru's PRS.

A second judicial option would be for the Appellate Body to reverse course and apply conflict rules under international law, such as Article 41 of the Vienna Convention, since the WTO Agreement does not expressly prohibit inter se modifications of WTO rules, and parties should be granted the contractual freedom to update the trade rules that apply between them. The WTO Appellate Body could likewise recognize that FTA rules constitute 'consent' to a measure that would otherwise violate WTO obligations, and thus preclude a finding of wrongful conduct (per Article 20 of the ILC Articles), provided (i) that the consent is sufficiently clear and (ii) that other WTO Members are not adversely affected by it.

A third judicial option, which we advance, is to permit a defense under an FTA so long as the respondent proves that the FTA meets the two core requirements under GATT Article XXIV regarding FTAs, namely (i) liberalization of 'substantially all trade' among FTA members; and (ii) not raising trade restrictions against other WTO Members. ${ }^{43}$ The additional conditions that the Appellate Body cited from its earlier Appellate Body decision in Turkey-Textiles should not be relevant (such as necessity for the creation of an FTA) since those conditions come from the preamble of paragraph 5 of Article XXIV concerning the raising of a defense against a MFN violation. Unlike Turkey, Peru was not raising new trade restrictions against a non-FTA party in violation of the MFN clause, but rather only against an FTA party, and with that party's express consent. Under this third option, defenses could be raised under an FTA, but only provided there was no successful challenge that the FTA did not meet GATT Article XXIV's two core requirements.

Were the FTA's consistency with GATT Article XXIV to be addressed and the Appellate Body to find that the FTA was inconsistent with either of these two GATT Article XXIV requirements, the Appellate Body would then decline to recognize provisions of the FTA as a defense to WTO rules. This approach would help to discipline FTAs, and encourage FTA members to negotiate agreements that are consistent with GATT Article XXIV. Nonetheless, this approach runs the risk that the political and judicial stresses of actually verifying the consistency of FTAs with GATT Article XXIV - a task that the GATT and the WTO have studiously avoided - would worsen the current political stalemate in the WTO. 


\section{Three political options}

If the Appellate Body's dicta in Peru-Additional Duty effectively eliminates the ability of WTO Members to raise FTA defenses, then WTO Members can turn to political options that range in their ambition. First, in complement with the first judicial option, individual WTO Members could write into their FTAs clear and express waivers of their rights to bring a WTO complaint in relation to specific measures (such as Peru's PRS). The Appellate Body already has recognized that it must interpret other international treaties, whether in the context of waivers, interpreting WTO obligations, or interpreting WTO provisions that incorporate other international treaties (Pauwelyn, 2016).

Second, if the Appellate Body does not change its position, a more ambitious solution would be for the WTO membership to create a protocol confirming that WTO panels and the WTO Appellate Body are authorized to raise FTA provisions as defenses to WTO claims, so long as the defense does not prejudice the rights or obligations of any WTO Member that is not a party to the FTA. Such confirmation signals to the Appellate Body that WTO provisions for amendments of the WTO agreements (applying to all WTO Members) do not supersede Article 41 of the Vienna Convention concerning inter se modifications of rights and obligations as a defense to a WTO complaint.

Third, a much more ambitious approach would be to transform the WTO dispute settlement system into a system of general jurisdiction for all trade agreements that contain a compromissory clause recognizing its jurisdiction, and that provide adequate funding to support any necessary expansion of the WTO secretariat, panels, and Appellate Body (Trebilcock, 2015). The WTO already hires additional secretariat members for particular cases (the Boeing (US)-Airbus (EU) cases being a notorious example) and panelists are funded on an ad hoc basis. Such adaptation is easily conceivable, although the membership of the Appellate Body may need to be expanded slightly.

Under this scenario, the WTO dispute settlement system would be able to hear complaints, as well as defenses, under FTAs. New issues would of course arise based on the FTA's updating and clarification of trade rules. That is not a problem, however, because it is what the WTO as a negotiating forum was supposed to do. Since the Doha Round of trade negotiations has collapsed, and since the political process for updating and clarifying rules has migrated to FTAs, this approach contends that the WTO dispute settlement mechanism should be adapted. Otherwise, the WTO judicial process and the FTA political process will be in tension, imbalanced, and incoherent. Such a more pluralist approach to trade negotiations, moreover, could have the advantage that it facilitates the ability of sovereign countries to tailor rules to their differing contexts in a diverse world. The WTO institution would, under this scenario, remain critical in keeping FTAs under multilateral surveillance so as to ensure greater trust and 
potentially facilitate their inclusivity over time, possibly leading to the amendment of WTO rules for the entire membership.

It is unlikely that WTO Members can reach agreement over either of the last two political options, given the difficulty of reaching consensus among over 160 WTO Members. Thus, pressure will increase on the Appellate Body to interpret WTO rules for today's changed landscape, and to find ways to accept defenses under WTO-consistent FTAs. As trade agreements proliferate and possibly extend to mega-regionals such as the TPP, the WTO needs to stay relevant. One way is by contributing to the systemic integration of politically negotiated trade outcomes through the WTO judicial mechanism. In its very first case, US-Gasoline, ${ }^{44}$ the Appellate Body wrote that WTO rules should not be read in clinical isolation from public international law'. The WTO Appellate Body has integrated public international law concerns over the environment and public health through its interpretation of the open-ended language of GATT Article XX. The new challenge for the Appellate Body is how to address the sprawling world of FTAs in WTO jurisprudence.

\section{Conclusion}

Peru-Additional Duty raises the question of how a WTO dispute settlement panel and the Appellate Body should respond when a party accepts a measure in an FTA and then brings a complaint that the measure violates WTO rules. It is not an isolated issue. Studies show that significant numbers of FTAs contain provisions that appear to cut back on WTO liberalization requirements as applied among FTA Members, such as regarding export restrictions (Zhang, 2016).

Peru bound its tariffs for the four categories of agricultural products in question at $68 \%$. It then lowered its applied tariff rate to $0 \%$, but subject to a Price Range System where tariffs can increase on a fortnightly basis (although no more than the binding) if the international market price is less than the monthly average price over the previous five years. In parallel, Peru signed a series of FTAs where the contracting parties arguably consent to its use of the PRS. The Appellate Body, however, following its earlier jurisprudence in Chile-Price Band System, held that the PRS was effectively a variable import levy and likely a minimum import price in violation of Article 4.2 of the WTO Agreement on Agriculture.

A critical question, nonetheless, remained: whether the Peru-Guatemala FTA, which provides that Peru 'may maintain' the PRS, could be used as a defense. The panel avoided the issue by noting that Peru had not ratified the FTA. The Appellate Body, in contrast, went beyond this reasoning and suggested that FTA rules cannot be used as a defense. Such a suggestion has significant systemic

44 Appellate Body Report, United States - Standards for Reformulated Gasoline, WT/DS2/AB/R (adopted 29 April 1996). 
implications, especially given global political developments and the proliferation of FTAs. It might appear presumptuous for a WTO tribunal to find that WTO rules always trump FTA rules regarding Members' policy space. This seems particularly problematic when the FTA complies with WTO requirements, and the FTA rules are later in time, directly on point, respond to dissatisfaction with an earlier Appellate Body ruling, and do not adversely affect other WTO Members. As we have shown, public international law provides rules that enable a panel to avoid an outcome that would violate the FTA parties' clear intent. An ongoing challenge for the WTO and its Members is how the WTO dispute settlement system engages with FTAs. The saga continues.

\section{References}

Bagwell, K. and A. O. Sykes (2004), 'Chile-Price Band System and Safeguard Measures Relating to Certain Agricultural Products', World Trade Review, 3(3): 507-528.

Bartels, L. (2001), 'Applicable Law in WTO Dispute Settlement Proceedings', Journal of World Trade, 35 (3): 499-519.

GATT (1993), 'Modalities for the Establishment of Specific Binding Commitments under the Reform Programme: Note by the Chairman of the Market Access Group', MTN.GNG/MA/W/24, 20 December 1993, Geneva, GATT.

Hathaway, D. E. and M. D. Ingco (1995), 'Agricultural Liberalization and the Uruguay Round', paper presented at The Uruguay Round and Developing Economies, a World Bank Conference, 26-27 January 1995.

International Law Commission (2001), 'Responsibility of States for Internationally Wrongful Acts', United Nations.

Marceau, G. (2001), 'Conflicts of Norms and Conflicts of Jurisdictions: The Relationship between the WTO Agreement and MEAs and other Treaties', Journal of World Trade, 35(6): 1081-1131.

Natens, B. and S. Descheemaeker (2015), 'Say it Loud, Say It Clear: Article 3.10 DSU's Clear Statement Test as a Legal Impediment to Validly Established Jurisdiction', Journal of World Trade, 49(5): $873-890$.

Pauwelyn, J. (2003a), Conflict of Norms in Public International Law: How WTO Law Relates to other Rules of International Law, Cambridge: Cambridge University Press.

(2003b), 'How to Win a World Trade Organization Dispute Based on Non-World Trade Organization Law?', Journal of World Trade, 37(6): 997-1030.

(2016), 'Interplay between the WTO Treaty and Other International Legal Instruments and Tribunals: Evolution after 20 Years of WTO Jurisprudence', International Law Reporter, 19 February.

Saggi, K. and M. Wu (2016), 'Understanding Agricultural Price Range Systems as Trade Restraints: PeruAgricultural Products', World Trade Review, 15(2): 259-286.

Sampson, G. P. and R. H. Snape (1980), 'Effects of the EEC's Variable Import Levies', The Journal of Political Economy, 88(5): 1026-1040.

Shaffer, G., P. Elsig, and S. Puig (2016), 'The Extensive (but Fragile) Authority of the WTO Appellate Body', Law and Contemporary Problems, 79: 237-274.

Shaffer, G. and J. Trachtman (2011), 'Interpretation and Institutional Choice at the WTO', Virginia Journal of International Law, 52(1): 103-153

Shaffer, G. and L. A. Winters (2016), 'FTAs as Applicable Law in WTO Dispute Settlement: Was the Appellate Body Wrong in Peru-Additional Duty (DS457)?’, Working Paper No. RSCAS 2016/65, Robert Schuman Centre for Advanced Studies, European University Institute, Florence.

Trachtman, J. (1999), 'The Domain of WTO Dispute Resolution', Harvard International Law Journal, 40: 333. 
- (2004), 'Book Review: J. Pauwelyn, Conflict of Norms', American Journal of International Law, 98 : 855.

Tracy, M. (1989), Government and agriculture in Western Europe 1980-1988, 3rd edn, New York: Harvester.

(1994), 'The spirit of Stresa', European Review of Agricultural Economics, 21(3-4): 357-374.

Trebilcock, M. (2015), 'Between Theories of Trade and Development: The Future of the World Trading System', The Journal of World Investment and Trade, 16(1): 122-140.

Zhang, W. (2016), 'Tracing GATT-Minus Provisions in Export Restrictions in Regional Trade Agreements', Global Trade and Customs Journal, 11(3): 122-133. 